\title{
AND THE DEAD REMAIN BEHIND
}

\author{
PETER READ \\ A nd only now have I learned \\ What exileis: gravestones \\ Silent in a foreign language ${ }^{1}$
}

I

$\mathrm{n}$ most cultures the dead and their living descendants are held in dialogic relationship. Therefore to fail to carry out what is culturally required for one's family dead can be exquisitely painful for those unable to do so. A Czech Jewish woman related how she could not return to her village birthplace to salute the 48 family members killed by the Nazis and their sympathisers, prevented not by a physical force but the thought of meeting, accidentally, the persons or their descendants who had participated in the slaughter. ${ }^{2}$ Croatian villages destroyed during the 1990s war are still sown with anti-personnel mines, in the cemeteries as much as around the town halls. It will be beyond the lifetime of the old people before the mines are cleared. ${ }^{3}$ But the Chinese, with the help of a priest, may summon the soul of an ancestor from an Asian grave to an Australian temple, where the spirit, though removed from its earthly vessel, will rest and remain at peace. ${ }^{4}$

Forgotten and abandoned, too, are many of the graves in Jewish cemeteries of Nazi occupation, for those who had the care of tending them were themselves obliterated. Other European Jewish cemeteries deteriorate because the descendants of the buried fled into exile and have not returned.

Some 7000 Jewish Holocaust survivors came to Australia before 1950, for many of whom the act of return to the ruined cemeteries of Germany, Poland, Hungary or the former Czechoslovakia has been one of appalled discovery rather than loving maintenance. The children of exiles, groping at the meaning of the destruction of the dead as well as the living, wrote poetic and poignant expressions of their anguish under the interdiction of their old people: Y ou must understand. But you cannot, you were not there. $^{5}$

One such child of exiles was the Australian writer Arnold Zable, who visited the Polish city of Bialystock. Near the city, since 1943 almost empty of Jews, was an ancient cemetery. Zable, searching for his ancestors, walked in widening circles for an hour before he found the first grave, and wrote: 
Soon I have located about a dozen, slung between shrubs and long grass. There are no headstones, not a single Hebraic letter, merely 6 body length slabs, others lying like solidified slugs glistening in the sun.

Perhaps this is how it has always been for descendants of lost families: we search within a tangle of aborted memories while stumbling towards a mythical home which seems to elude us as it re cedes into false turns and dead ends. For while the old man talks I am overcome by an uncanny feeling that there are many of us at this moment - sons, daughters, nieces, nephews, grandchildren - wandering country roads and city streets, or picking our way through forest undergrowth to uncover mould-encrusted tombstones.7

So in Latin America, where in many countries temporary flight from anarchy or a new and vengeful government has become expected and almost institutionalised. Permanent enforced exile is different, not least because sometimes absence is not expected to be forever. People in flight rarely think of the longterm consequences of a permanent departure, but for many an ageing exile, the birth land calls louder every year. The unlooked-for meditation on places once loved and objects abandoned becomes an ache transfixed in a transplanted culture never quite matching the old, the mind alighting upon friends unvisited, a family ageing and uncared for. Mystification, ignorance and finally indifference overtakes the succeeding generations of the children of exiles.

In Cuba many of those who fled from Castro's revolution had already spent periods in Mexico, or Guatemala or the US. Often women and children didn't bother to leave while the men endured or enjoyed - a year or two away from domestic or workplace responsibility. In 1959 they left Castro's Cuba in the same expectation that they would triumphantly return within a year or two. The failure of the Bay of Pigs invasion was the first intimation that they might re main forever in exile, their lost places forlorn, their culture truncated: and the graves of their ancestors uncared for.

The family tombs, like the Croatian and the Jewish, were neglected in the first abrupt departure. Gradually they infiltrated the consciences of Miami exiles who realised, too late, that responsibilities towards the ancestors, the pain of severed relationships and the obligations of family honour would remain forever unfulfilled. They imagined, we suppose, the once elegant family tombs in $\mathrm{Ha}$ vana's principal cemetery, Cementerio Colón, as the photographs of the dead gathered dust, the paths grew weedy and the inscriptions faded, while over all settled an air of melancholy neglect.

It is only recently that they have begun to learn what has in reality occurred to the tombs of Cementerio Colón. What began as a twinge of the conscience has become one of the heaviest costs of permanent exile.

Cementerio Colón, Havana, is one of the largest, and still most dramatic, cemeteries in the whole of Latin A merica. It is by no means the best kept: that of Santiago De Cuba is much better maintained, but since perhaps two million people have been buried in Cementerio Colón since it opened in 1879, the authorities have good excuse for its comparative disrepair. And they are trying hard to restore it. The City Historian Eusebio Leal, who has charge of the general reconstruction of Old Havana, and 
who began the restorations of the ceme tery in the mid 1980s, is said to wander its huge area planning which areas are next to be restored. The oily pools and unpleasant smells which disfigured the cemetery during the terrible Special $\mathrm{Pe}$ riod beginning in 1991 (in which Cuba, on the departure of the Russians, was left without resources) have all but vanished. The guidebook claim that the Cementerio Colón is 'the best monumental architectural cemetery in the world', may be an exaggeration, but the central avenues are splendid indeed. 8

It'll cost the tourist a dollar to enter, nothing if you're visiting a relative.

The first impact on the visitor is blinding white, heat, few shade trees and nowhere to sit. Straight in front, at the axes of the principal avenues Avenida Cristobal Colón, Obispo Espada and Obispo Fray Jacinto, stands the Central Chapel apparently modelled on II Duomo in Florence. On every side rectangular streets lead geometrically to the cemetery's 56 hectares, designed by the architect Calixto de Loira to define the rank and social status of the dead with distinct areas: priests, soldiers, brotherhoods, the wealthy, the poor, infants, victims of epidemics, pagans and the condemned. 9 The best preserved and grandest tombs are on or near these central avenues and their axes.

The first casual stroll from the entrance to the Central Chapel reveals pride and achievement in the city's and the nation's culture. Elegant sculptures of La Virgen de la Caridad del Cobre, Cuba's patron saint, form the focus of many a monument. A breathtaking nineteenth-century memorial recalls the bravery of the city's firemen. The massive Fuerzas Armadas Revolucionarias, a graceful marble open-air pantheon con- taining the remains of national heroes is guarded by the two saluting bronze figures. A perambulation down the main thoroughfare and through the chapel leaves little to suggest that the country has been under the rule of a revolutionary government for 44 years. Nor does the city cemetery, from this vantage point, bear indication of the sudden and permanent departure of the many hundreds of sons and daughters whose task it was to care for the family tombs of their ancestors.

A way from the central avenues the cemetery begins to offer the historian something more than national heroes and a range of architectural styles from classical to modernist to Renaissance to bizarre. Its calculated resemblance to a real city, of central plaza, administration, grand avenues, humble streets and suburbs from very rich to very poor, speaks the life which in prerevolutionary $\mathrm{Ha}$ vana existed outside the cemetery walls. In the Latin American Catholic tradition, what was mounted about the tomb was frequently rather more important than what the tomb contained. In the richer precincts, tombs competed with each other in opulence, architectural daring or familial piety, or trumpeted the family achievement. And of course the ceme tery, like the city, is a place of miracles. Doña Amelia de Gloria Castellano (Amelia Goyre) died in childbirth in 1901 with her baby buried beside her. When the coffin was opened, the baby lay in its mother's arms.

Stroll down, say, to a quiet corner in Calle 10. A man has stepped from his 1956 Chevrolet to place a bunch of flowers on a well kept grave. Over here, look at the marble figures of remarkable grace and feeling. In the distance an exhuma tion is taking place, for a coffin has ful- 
filled its allotted two years in the ground and the space is needed for another burial next week. An extended family group of a hundred people are taking part in what is effectively a second funeral as the coffin emerges from the ground. In the next few days the bones will be reburied in a cement box and placed in storage with the hundreds of thousands of others that can be seen stacked in several more or less discreet parts of the cemetery. After seeing a program depicting an exhumation in Cementerio Colón on television, Nedda de Anhalt wrote:

\author{
Unas manos desgajan los restos de carne \\ Putrefacta de un esqueleto \\ Que aseguran es el de mi padre. \\ Pero yo se que esos huesos \\ Pertenecen a una desconocida. \\ Cubro con un pañuelo \\ Mi boca y nariz \\ Mientras con la otra mano \\ Sostengo en alto \\ Una rosa. \\ (Some hands tear off the rest of the \\ Putrefying flesh of a skeleton \\ They assure me that it belongs to my fa- \\ ther. \\ But I know that these bones \\ Belong to an unknown woman. \\ With my mouth and nose \\ Covered with a handkerchief \\ I hold out from above \\ A rose. 10
}

And just over here a group of cemetery workers are disinterring half a dozen coffins of - who knows who they were? The coffins seem to have neither identification nor mourners. The men toss them around as they lever off the more valuable lid from the unwanted pine box. The contents spill in ungainly heaps over the ground. The remains of the corpse, clothes, bones, loved objects, and faded letters blow about in the wind, to wait, while the pedestrian hurriedly chooses another path, to be shovelled into the trailer.

Such sights should not be altogether surprising in a nation at times desperately poor, without a crematorium, in an overcrowded cemetery with attitudes to death rather more frank and disclosed than in Anglo Saxon countries. Nobody has resources in Cuba to spend on the preservation of family graves. The best that can be expected is to keep the tomb swept and tidy, change the flowers and to replace the funerary objects decaying with age.

Yes, abandoned tombs can be re stored by the state. But state finance or heritage consciousness won't fill the empty tombs, replace the photographs, or do anything to restore the personal honour that once belonged to the exile families, nor still the sense that ancestors have been abandoned to decay and destruction by the people who should have cared for them. And the state certainly won't spend any money on the tombs of those judged to have been enemies of the revolution.

Consciousness of unfulfilled obliga tions and besmirched honour hang heavily on exile communities. To preserve those obligations was the reason why Cuban exiles in Miami drank a toast each new year's eve to 'Next year in Cuba'. Not to do so was to show that one had given up the hope of return, or as years went by, the pretence of the hope of return. Not to do so meant that the exiles had forsaken the sacred trust to care for their inheritance, not least the tombs of their own parents and grandparents. Some Cuban Americans, indeed, sent large sums of money from Spain or 
the United States for tombs to be re waxed to prevent the entry of moisture, or to repair the chapels and mausoleums. The first indication of overseas concern is the inscription 'clausurada' on several tombs. It means 'closed', indicating that someone has paid a sufficient sum for the coffins inside either not be removed, or not to have other coffins placed upon them. Almost certainly that instruction, and the sum in US dollars, has been sent from abroad. Others, from abroad, ask their friends to place flowers on the grave of their mother on Mother's Day.

Most revealing whether or not a tomb has a local family protector, is the condition of the shrines, little chapels usually with windows and a glass or metal door. In these were placed, at the time of interment, perhaps a Madonna, devotional objects, a shelf holding several photographs, urns, flowers - and a broom. Some contain curtains, a chair, personal items of the deceased, so that the tomb becomes simultaneously a private room sealed - it was hoped - for eternity. A tomb well kept by local families may be in disrepair, but the flowers will be changed from month to month, the vases and photographs dusted, rust and water stains scrubbed off. The family members will be too busy keeping their heads above Cuba's perilous economic waters to spend money on upkeep even if the materials for repair were available.

It is the others on which our tour is focused, of much worse condition. These are the unprotected tombs and chapels of the Havanans who have abruptly departed within the last 44 years and have not returned. A stroll in any direction from Colón Avenue will make apparent the differences.

We begin in the Northwestern quadrant.
This tomb - as can be seen by peering in the window - has been stripped of everything movable. The remaining urns, once white and fixed to the floor, are stained with lichen or dust. Walk onwards a few paces to another where a jagged triangular piece has been ripped from the floor of this chapel which forms the roof of the tomb below. The door is locked, making it impossible to see what lies beneath. Pieces of the smashed segment lie about, and a lump of cardboard. At some point the space has been swept, and a neat but mysterious pile of grey and white stony rubbish lies on the re maining section of the floor.

In this next grave, $\mathbf{2 0}$ metres further, the curtains once adorning the chapeltomb have rotted and turned dark with age. The sagging holes and blackening fragments dropping onto the marble bench beneath lend the tomb an aspect more of macabre mutability than perpetual peace. A photograph on the shelf has inexplicably fallen on its face. Opposite, another tomb is entered by an exterior staircase which appears not to have been disturbed for 40 years: one would need a machete to make an entrance.

Continue further to the next street.

The glass door of this chapel is smashed: only an iron grille prevents entry to the colourfully painted $\mathrm{Ma}$ donna, who, standing on a plinth, almost touches the barrel vaulted roof. She's still beautiful, but is surrounded by a wheelbarrow, tools, cement bags, boxes and lumps of monumental masonry. Oddly she does not seem so out of place here in the detritus as the Madonna in that empty violated tomb who presides over nothing.

The glass windows in this tomb have evidently been broken and crudely re placed with hardboard. Plaster falls off a 
corner to reveal the mundane brick beneath. Another adjacent chapel has a smashed and broken door. One can enter to peer four metres to the bottom of the vault. All its former occupants have been removed. Why? Where to? When? When the city's regular churches were closed or politically difficult to enter, individuals sometimes used tombs as a private or family shrine, and perhaps still do. But why remove the coffin if the space was not intended for another? Perhaps that topless, empty chamber was robbed first of its Carrara marble. Perhaps someone in downtown Havana is enjoying dinner on a very heavy white tabletop. The Cuban people have lived through some desperate times since 1959.

The sudden cut-off from the long dynasties expected and assumed to flourish in Cuba for ever, is never so clear as in the mausoleum of the family Nuñez Galvez. It's an avant-garde though now deteriorating 1950s piece of architectural bravura. The names of the deceased Nuñez Galvez family follow in an orderly procession until they halt abruptly six months before the revolution:

$\begin{array}{ll}\text { NUÑEZ ALMAGUER } & \text { AGO 3DE } 1898 \\ \text { NUÑEZ PEREZ } & \text { ABR 4DE } 1903 \\ \text { - TERO CARRION } & \text { ENE 12 DE } 1908 \\ \text { NUÑEZ PEREZ } & \text { NOV 22 DE } 1912 \\ \text { NUÑEZ QUINTERO } & \text { ENE 12 DE } 1932 \\ \text { NUÑEZ BASULTO } & \text { JUL 17DE } 1958\end{array}$

The most strikingly modern and one of the most beautiful 1950s tombs in the cemetery is the mausoleum of the journalists of the newspaper El Pais, the Reporters Association Pantheon. The above ground level section is a semi-elliptical glass, three metres deep. Glass panels form both sides of an entrance chamber, perhaps to represent the transparency of truth. The reinforcing beams allude dra matically to the shape of a cross. Although the architect has installed a little window into the tomb at knee height on Calle J, it will be worth entering this arresting edifice. Mounting the seven steps to the formal terrace reveals that some of the glass panels have been smashed making an easy entrance.

Below the entrance level area a staircase descends to two levels below ground. Descend half a dozen steps as the strong Havana sun weakens and filters into columns of airy dust. In this sombre light it's difficult to subdue the emotions, for the tomb bears an ambience both sinister and strange. The weird inscriptions on a wall and pillars, and a general air of abandonment we'll return to after investigating the bottom level. The shadowy darkening staircase continues downwards to invite the curious and the strong minded.

To the bottom chamber and perhaps to what one should expect in a country having endured more than one Special Period of starvation and neglect. Strange groups of letters are painted on the roof, KKK, and a word beginning NEOR. Lidless cement boxes of bones lie everywhere. A bout half the chambers reserved for them along one of the walls are filled, the names of the deceased painted crudely on the outside. A dozen boxes lie on their sides or upside down, their contents spilling onto the floor. One lying at the bottom of the stairs has several human bones emptied in the middle of the floor resting on a pile of tiny white and grey fragments. So that's what those pieces are in the empty tomb on Calle F, parts of exhumed and destroyed bodies! One can imagine the course of events: a coffin in the empty tomb in the northwestern quadrant evidently was raised 
and emptied onto the floor of the chapel and the corpse ransacked - perhaps in the hope of extracting its gold teeth or jewellery, perhaps for the skull. Probably the robbery and desecration was discovered soon after by the cemetery workmen, who perfunctorily swept the remains into a cardboard box and left the rest in a pile on the floor.

Round the corner of this bottom chamber is a pile of another dozen boxes, their contents spilled over each in a grotesque pile of leg bones, clothes, hands, skulls, and other unrecognisable body pieces. Sprawled on top of the extraordinary charnel is what appears to be the blackened bottom half of a naked human form.

Surely this is the other side of the coin of life. The bottom level of the Tomb of the Reporters is not meant for anyone other than men working in a preparation area more casual than disrespectful, where labourers reminiscent of Hamlet's sardonic gravedigger go about their business.

Now ascend the stairs to the first level to the opaque filtering light and the mysterious poems. A huge, high chamber, one side of which contains the words and markings, the other a grid of burial chambers. They are like the spaces below but much bigger, a metre square, in which a coffin was intended to be pushed and the entrance sealed. Some spaces are indeed sealed and the generous proportions and elegance of the chamber mark the interior as well as the glass ellipse as one of the most exquisite mausoleums in the land. A first glance reveals what the tomb was meant to be. A second glance reveals what it now is. A third pinpoints the nightmare of all those charged with the care, across many con- tinents and many centuries, of the re vered and solemn dead.

Some of the spaces intended for coffins are empty. Were they once filled? Several others have been broken into with a pick or a sledge hammer. Some appear to contain whole coffins, others only the black and shattered remains. Pieces of human body lie athwart the smashed coffins or on the floor. What looks like a rib cage is half inside a coffin, half out. Small and large pieces of bone and dark flesh are scattered in the shadows.

Written on the wall, mainly in what looks to be the same elegant hand, in black paint, are a number of verses. Some are inscribed four metres from the floor, way out of reach of a normal hand. All are weirdly poetic reflections on death and cemeteries. One reads:
Al fin de la vida pensamientos
Hasta entonces no pensados
Surgen claramente del espíritu
Son como genios chistosos que se
Posan deslumbrantes en la cima
De lo pasado
(At the end of life thoughts
Unimagined until now
Rise clearly from the spirit
They are like whimsical beings which
Throw dazzling light on the summit
Of what has been)

Others read, 'Life is not only a track, rather it's a form of living for those who know how to live it'. The most sinister of all, hard to read because it so high, de claims 'Those who are condemned to die should not be condemned for defending the right to live'. Who could have written such sentiments in such bizarre surroundings? Was the Pantheon - is the Pantheon - a chamber of torture as well 
as death? Were the Reporters selected for some after-death punishment, and by whom? Or does this appalling desecration flow from some independent motive? The deep silence, the heavy air, the threatening lowering violence, the enigmatic texts, the shadowy light, the baleful ambience, the spiritual menace which threatens at any moment to materialise: surely this most sinister of tombs deserves a less prosaic lament than the lament of a Miami exile after visiting the cemetery:

Al parecer serán tomadas medidas inmediatas de vigilancia con un cuerpo de serenos para que los disfuntos puedan descansar en paz ... y sus familiares tambien. (It appears that they will take immediate measures to establish cemetery viligantes so that the dead can rest in peace... and also their families. $)^{11}$

One Cuban American website on Cementerio Colón concludes with the observation:

El Cementerio Colón es un testigo mudo del deterioro de nuestro país despues de la revolución de la desgracia del comunismo.

(The Colón Cemetery is a testimony to the deterioration of our country since the revolution of the disgrace of communism.)

But to limn the horrors of the shadowy Tomb of the Reporters is not necessarily to make a political judgement on Castro's government. There is no indication that the government wishes the cemetery to be in such a state; indeed the advance of Afro-Cuban mortuary practices is decidedly unwelcome to the re- gime. Rather we should embrace the universal human emotion that the bones of the dead deserve to be left in peace, and that the rights and wrongs of revolution and exile ought to be irrelevant beyond the grave. ${ }^{12}$

Outside in what the Australian poet Judith Wright calls the strict chains of day, amidst the majestic ordered solemnity of Avenida Obispo Fray Jacinto, the Tomb of the Reporters seems far away. But it's not. Take a half glance towards the junction of Calle $J$ and Calle 14 and the sun will be glinting from the tall glass wall and its elegant entrance. The Tomb of the Reporters is always present at the edge of vision, in the blink of an eyelid, a moment in the mind, just a step from the broad sunlight of the serene and honoured monuments of this A venue into its gathered darknesses.

Here in the full heat and light of midday stands the severely dignified tomb of the family Prío Socorrás, containing the remains of the mother of the last freely elected president of the $\mathrm{Re}$ public, Carlos Prío Socorrás. Probably the tomb has not been opened since her interment. Prío, an exile, not from Castro, but from his predecessor, Fulgencio Batista, left the country early in 1952. The family is lucky that its tomb stands in the central avenue making an undiscovered desecration or robbery unlikely.

Where is the family continuity? Where is the tomb of her more famous son? Prío lived and died in the United States. ${ }^{13}$ In leaving his relatives dead and uncared for in the old country, he lived and died in the new.

Those exiles who for much of their lives were haunted by the memories of deep filial obligations unfulfilled, aged in a new country; and as they aged they became preoccupied with a personal 
problem yet more grievous: their own deaths in alien soil. Carlos Prío Socarrás and thousands like him are buried in $\mathrm{Mi}$ ami. They died in a new country. That's where our story continues.

\section{NOTES}

1 The Lithuanian poet Alfonsas NykaNiliunas, www.efn.org/ valdas/ nyka.html, accessed 26 A pril 2003.

2 P. Read, Returning to $\mathrm{N}$ othing, (M elbourne: Cambridge University Press, 1996), pp. 29-30.

3 P. Read,'Fantasy on One Note', in A. Curthoys and A. McGrath eds, W riting $\mathrm{H}$ istory: Imagination and $\mathrm{N}$ arrative, (Melbourne, Monash Publication in History, 2000) p. 41.

4 P. Read, Haunted Earth, (Sydney: University of New South Wales Press, 2003), pp. 127-141.

5 Arnold Zable, Jewels and A shes, (N ewham: Scribe, 1991), pp. 163, 66, 74.

6 Zable, Jewels and A shes, p. 66.

7 Zable, Jewels and A shes, p. 79.

8 The Guide to the Cristóbal Colón N ecropolis in Havana, (H avana: Com-Relieve SA, FidEscudo De Oras, SA, EEC, 1999), p. 17.

9 The Guide to the Cristobal Colón N ecropolis, p. 17.

10 ww.elateje.com/ 0307/ poesia030701.htm

11 www.rose-hulman.edu/ delacova/ religion/ santeria-huesos.htm, accessed 12 July 2003.

12 www.cubanmotives.com.Espanol/ Articulos/ Maria_Vizcaino/ el cementerio_de_c, accessed 15 July 2003.
The explanations are various, and all have some validity: that the Special Period made the living so desperate that Havanans robbed the dead of their gold fillings and jewellery. Graves were robbed also of their marble slabs and ornaments.

Some Pro-Cuban religious cults such as EI Palo require certain body parts such as fingers and pieces of skull to enable the living cultist to join in union with the dead. The cemetery guidebook (see above) explains that:

The initiate affirms that he is admitted into the life of the deceased, and from that moment onwards he is identified with death and the spirits recognise him as one of their own (p. 90).

For this reason, it is alleged that skulls cost between $\$ 20$ and $\$ 30$ (www.rosehulman.edu/ delacova/ religion/ santeria -huesos.htm, accessed 12 July 2003); see also 64.21.33.164/ CNews/ y98/ may98/18a5.ht $\mathrm{m}$, in which it is alleged that $a$ grandmother saw someone with some burial clothing of her granddaughter three days after her burial. Other cults, Protestant in origin, are practised among the cemetery tombs. Natalia Bolivar affirmed that she was eye-witness in 1995 to a nocturnal police raid on the Tomb of the Reporters, in which a group of gay cultists were arrested for Satanic practices. It seems probable that the wall inscriptions were written by members of this group.

13 www.wikipedia.org/ wiki/ Carlos_Prio_Socarras, accessed 11July 2003. 